\title{
Eleanor Bell \\ Ian Rankin and the Ethics of Crime Fiction
}

What crime fiction needs is a sense of the incomplete, of life's messy complexity. The reader should go to crime fiction to learn about the real world, not to retreat from it with comfortable reassurances and assumptions... Good does not always triumph in today's crime fiction; evil cannot always be rationalised. Sometimes the villains escape justice altogether, and in many cases the reader is invited to take sides with the assassin or criminal against the powers of law and order. There are even novels with no detectives and no mysteries, showing a world in which criminality, especially organised crime, operates openly and without hindrances. (Rankin 1999:12)

In his article 'Why Crime Fiction is Good for You' Ian Rankin reflects on the ethical imperatives at the heart of crime writing, suggesting that it ought to invoke a selfconscious interrogation of the dark underside of society, inviting the reader to probe beneath everyday appearances in order to better understand the complexities of modern identity and belonging (Rankin 1999:9). By drawing attention to the ethics of crime fiction, Rankin defends the genre against the common criticism that it is a debased form of literature. For Rankin, crime fiction allows access to the deepest recesses of society, to usually restricted areas, spaces the average reader would only want to engage with voyeuristically in print or on screen. 'Good' crime fiction therefore encourages an active sociological reading, where the reader becomes an armchair detective of the world around them. Much of Rankin's fiction engages with Scottish politics and society in this way, most recently presenting an analysis of the unsettling forces at the heart of postdevolution Scotland. Central to Rankin's fiction therefore is strong sense of Scotland in transition, a movement into twenty-first century global uncertainty and what might be thought of as a more postnational vision of the nation. In this way Rankin extends the notion of crime as a continual, disruptive, unknown force to the national level, implying 
that the nation is also in a process of continual evolution, one also full of mystery and lacking assurance. Following critics such as J. Hillis Miller and David Parker, this article will suggest that in doing so Rankin encourages an ethical reading of the nation that is more focussed on exploring its repressed undercurrents and dark unconscious than with glorifying its heritage. In The Ethics of Reading (1987), J. Hillis Miller states that at the very heart of the ethics of reading lies its very impossibility, that meaning cannot ever be fully captured. ${ }^{1}$ Following Paul De Man, Miller refers to this as a process of 'unreadability'. Consequently, the discussion of the ethical in this article will concentrate on the ways in which Rankin's concerns with crime and nationhood also contain this element of 'unreadabilty', that while the nation is being depicted it is also in some ways being subverted at the same time. In doing so it will focus particularly on three of his novels - Black and Blue (1997), Set in Darkness (2000) and Fleshmarket Close (2004) in order to investigate the implications of this ethical potential, to question the extent to which Rankin's texts helpfully map a sense of the local and the ways in which this is complicated by the 'messy complexities' at the heart of these texts.

In Rebus's Scotland: A Personal Journey (2005), Rankin continues to reflect on contemporary crime fiction and his reasons for adopting the genre. While Rankin is keen to accentuate some of the fundamental differences between himself and his famous detective figure, John Rebus, what unites both is a deep fascination with place -

\footnotetext{
1 'It is impossible to get outside the limits of language by means of language. Everything that seems outside language, for example sensation and perception, turns out to be more language. To live is to read, or rather to commit again and again the failure to read which is the human lot... We struggle to read from the moment we wake in the morning until the moment we fall asleep at night, and what are our dreams but more lessons in the pain of the impossibility of reading, or rather in the pain of having no way whatsoever of knowing whether or not we may have in our discursive wanderings and aberrancies stumbled by accident on the right reading? Far from being "indeterminate" or "nihilistic", however, or a matter of free play or arbitrary choice, each reading is, strictly speaking, ethical, in the sense that it has to take place, by
} 
Edinburgh in particular, but Scotland and contemporary Scottishness by extension. Rankin, who was born in Fife, has written that he started writing the Rebus series in order to make sense of his adopted home of Edinburgh:

If my original project had been a greater understanding of the city of Edinburgh, those parameters soon changed, once I'd discovered that Rebus was a tough enough creation to lead the reader into an investigation of Scotland itself: a small, proud and ancient country with a confused sense of its own identity. This is the landscape I inherited, with Detective Inspector John Rebus as my guide. (Rankin 2005: 29)

For Rankin, then, a mapping of fictional worlds can clearly lead to an investigation of real-life ones, and this, it seems, is one of his primary motivations for creating the Rebus detective series. While such claims of verisimilitude may be problematic for many literary critics, it is perhaps this frisson between his constructions of Scottishness, on the one hand, and the 'real' world outside, on the other, that draws many readers to his texts and generates their popular appeal. A former postgraduate student of Scottish literature, Rankin frequently inserts Scottish literary references into his representations of the local and has often alluded to his particular debt to Robert Louis Stevenson's The Strange Case of Dr Jekyll and My Hyde (1886). While the doppelgänger motif is often readily associated with Edinburgh's Old and New Towns, this sense of a split self is also evident between Rankin and his alter ego, Rebus. As a result, Rebus's Scotland partly provides autobiographical accounts of both author and protagonist, alongside a journey into modern Scotland, 'the Scotland that the tourist never sees'. He asks 'can crime fiction ever give a true and all-embracing account of a nation? The answer should be a resounding 'Yes!' (Rankin 2005: 174)

an implacable necessity, as the response to a categorical demand, and in the sense that the reader must take responsibility for it and its consequences in the personal, social and political worlds.' (Miller 1987: 59) 
Throughout his detective series Rankin has therefore aspired to present authentic visions of Scotland, to reflect subtle changes of detail in Edinburgh life and provide persuasive representations of the nation in 'real time' (Rankin 2005, 31) ${ }^{2}$. While his texts may be ultimately unable to present 'a window on the world', like many other forms of crime writing and detective fiction, they do nonetheless provoke a deep and intimate engagement with place. While more sceptical critics, such as Ernest Mandel, have suggested that crime fiction in fact only functions as a form of escapism, presenting a perpetuation of the status quo rather than a means of societal or ideological critique (Mandel 1984: 10), for Rankin crime fiction has a more active role to play:

What interests me is the soul of the crime novel - what it tells us about humanity, what it is capable of discussing. Good crime fiction tackles big issues. My own crime novels have discussed the morality of big business, political corruption, child abduction, the drug scene, the ramifications of the oil industry and so on....We are all inquisitive and curious animals, learning through questioning, and crime fiction touches this deep need to both ask questions and to get answers. (Rankin 1999: 14-15)

Yet while Rankin is eager to reflect on contemporary Scottish society, he has clearly also been influenced by the American hard-boiled tradition (Plain 2002: 40-41). In many ways, we can view Rebus as stemming from the private eye noir tradition, a character who defends himself from the dark forces around him, like Raymond Chandler's Philip Marlowe, with the aid of significant amounts of luck, whisky and wisecracks. Similar to the private eye figure, who was left to battle against the consequences of desperate social change generated by forces such as the Great Depression or Prohibition, usually with little power to affect change, Rebus often appears to be fighting against impossible odds

\footnotetext{
2 'I took the decision early on in the series that John Rebus would live in 'real time'. That is to say, he would age between books. After all, if I wanted to write about the changing face of Scotland, it was more realistic if my detective was allowed to change too. Rebus is affected by every case that he works on, and carries with him the ghosts of every victim. Police officers have often commented that he feels real to them,
} 
from a Scottish perspective. Like Marlowe, Rebus is a lonely outsider figure, frequently in turmoil. In his book Noir Fictions, Paul Duncan writes that 'noir is all those things we fear in the back of our minds, the parts of ourselves we want to block out as they make us feel uneasy' (Duncan 2000: 7). The figure of John Rebus therefore grants us access into the darkest spaces of Scottish life, exposing some of the neuroses and most dangerous impulses at the heart of contemporary society. This focus on the macabre elements of Scottish life led James Ellroy to famously label Rankin 'the progenitor - and king - of tartan noir' in a dust jacket review of one Rankin's earlier novels, Let it Bleed (Rankin 1995).

In her article "The Hardboiled Detective as Moralist: Ethics in Crime Fiction", Sandrine Berges suggests that the ethical potential of Rankin's fiction lies in the need for the restoration of order at the heart of his texts. Berges asserts that by reading crime fiction the reader receives a form of moral training in how to rationalise and confront disturbances in the social order and that Rankin's work provides a particularly apposite example of this process:

In which way are the Rankin novels ethically valuable then? The novels say that the best detectives, those we are encouraged to admire and identify with, solve cases by being less abstract and more practical, by distancing themselves from the rules and focussing on each case as deserving a new answer, by becoming involved in an intuitive and emotional way as well as intellectually and physically, by being practised observers, not just of scene of crime details, but of human emotions and ambitions, and by being able to tap into a background of past experience which is relevant to the case in hand... These novels familiarise us with the idea that it is often more productive to address moral problems on a case by case basis, taking in particular features of a situation, rather than by applying rules in a blind, impartial and impersonal way. (Berges 2003)

and the Chief Constable of Lothian and Borders Police went so far as to state that he wished he had an officer like Rebus on the force - high praise, as far as I was concerned.' Rebus's Scotland, p.31. 
While many well-known critics of the ethics of reading, such as Wayne Booth (1988) and Martha Nussbaum (1990), might sympathise with this notion that fiction imparts moral guidance, that assessing fictional worlds can advise us on our own, it could also be suggested that the ethical potential of Rankin's fiction lies precisely in the ways in which it complicates this very possibility, in the ways in which it disturbs any convenient or reductive reading of identity and society. Arguably, then, and as will be developed later, perhaps what makes these texts ethical is their deferral of closure, the sense that the task of moral engagement for the reader will never be concluded, that in this respect there is always an ethical slippage of meaning beyond the text.

Like most of Rankin's fiction, Black and Blue contains several interweaving storylines. The novel revisits the infamous 'Bible John' murders, which took place in Glasgow in the 1960s, suggesting that not only is Bible John still alive, but that he also has a new imitator, Johnny Bible. While the reader is repeatedly exposed to Bible John's voice, which disturbingly interrupts the narrative flow at unexpected moments, unnerving the reader, Rebus is not privy to this information and only establishes the connection between Johnny Bible and his predecessor towards the end of the novel. Parallel to the Johnny Bible / Bible John plots, Rebus must also solve the murder of Alan Mitchison and shed light on the police corruption implicit in the Lenny Spaven case. We later find out, as in much classic detective fiction, that all of these cases interconnect. At the end of the novel Bible John kills his 'upstart' impersonator, yet evades arrest and makes his escape as Rebus is too slow in making the connection between these two characters. Meanwhile the Spaven case signals that the Scottish legal system is riddled with corruption and cover-ups and the Mitchison storyline features an incest case, revealing a vision of 
society that is twisted in most shocking and repugnant ways (strikingly reminiscent of Roman Polanski's famous hard-boiled cinematic example, Chinatown). Accordingly, one of the key aspects that emerges in Rankin's fiction, as pointed out by him in the introductory quote to this article, is that "good does not always triumph in today's fiction; evil cannot always be rationalised" (Rankin 1999: 12). Plots may converge yet crime is uncontainable. Much like the world of the American private eye in the Depression era, Rankin's texts often depict a chaotic and challenging terrain for his contemporary readers where crime is a continual and unsettling force.

One of the main forms of resistance to the traditional depiction of crime can be found in postmodern anti-detection, in texts which self-consciously parody the very notion of closure and convention implicit to the genre. An obvious example is Paul Auster's The New York Trilogy (1987), which inverts and defamiliarises the reader's expectations by presenting them with metafictional worlds without tangible foundation, with postmodern worlds where identity is fluid and where clues are equally unlikely to cohere. The first book of Auster's trilogy, City of Glass begins with the notion that 'the question is the story itself, and whether or not it means something is not for the story to tell' (Auster 1987: 13). In the second book of Auster's trilogy, Ghosts, we are introduced to a character, Blue, whose job is to monitor the actions of another, Black. In this story all of the characters have been symbolically pared down to basic signifiers, coded through colour or its absence, where identity is highly uncertain. In this way the text itself becomes a locked room, out of which it is difficult to escape. We are told that 'There is no story, no plot, no action - nothing but a man sitting alone in a room and writing a book. That's all there is, Blue realises, and he no longer wants any part of it. But how to 
get out? How to get out of the room that is the book that will go on being written for as long as he stays in the room?' (Auster 1987:172). While such works of postmodern antidetection often question the nature of existence, existing almost to raise metaphysical questions, in Rankin's fiction there is a much more traditional use of genre convention and a return to the 'real'. By comparison, Rankin's reference to 'Black' and 'Blue', stems from The Rolling Stones album of the same name, highlighting the importance of popular cultural references in his texts. However, at the heart of this depiction of the 'real' is also a clear sense of 'life's messy complexities', as pointed out by Rankin earlier. As Paul Duncan reminds us, reading noir 'is more likely to muddy the moral waters of our life rather than making us see in Black and White' (Duncan 2000:8). What emerges from this is that while it may not be possible to see the depiction of Scotland here in stark terms of 'black' and 'white', there is an implicit directive to engage with its grey areas, to dig beneath the surface.

Rankin's novels often represent the nation in transition in this way, drawing attention to the shifts that have taken place in Scottish cultural and political life in the past few decades, whilst also highlighting new paradigms, new uncertainties. As Gill Plain points out, like many of his other works, Black and Blue is therefore a 'state of the nation' novel, suggesting that while 'Rankin's Scotland is far from picturesque' (Plain 2002: 27), it explores the boundaries between tradition and modernity that help to situate it in the contemporary world. Accordingly, Rebus is faced with many new literal and metaphorical boundaries to cross 'complicating the reader's sense of Scotland as a coherent national unit' (Plain 2002:27). References to cultural and political theorists of Scottish society therefore characterise his fiction. Towards the end of Black and Blue, for 
example, in the section 'North of Hell', Rankin quotes the now-famous lines by Tom Nairn that 'Scotland will be reborn the day the last minister is strangled with the last copy of the Sunday Post' (Nairn 1970: 34). This scathing critique of Scottish parochialism by Nairn, published in his article "Three Dreams of Scottish Nationalism" in 1970 was viewed as highly controversial by many at the time and subsequently. It is therefore timely and telling that Rankin quotes these lines during a time of potential rebirth in Scottish cultural and political life. Instead of providing moral guidance, the text presents a reminder that while couthy, sentimental readings of identity no longer work, it is still unclear what will replace them. While the connections between crime fiction and their function as ideological critique are often contentious, what is of particular interest in relation to Rankin's fiction are the ways in which he establishes a paradoxical relationship between Scottish society and its critique at the same time. While there is a strong concern with mapping Scotland as a 'knowable' space, there is also simultaneously an awareness of the dark, unconscious, threatening forces at the heart of society that serve to disrupt this at some level. It is this paradoxical space which makes his engagements with Scottish identity so intriguing for his readers and critics. Implicit to his reading of nationhood is therefore an impulse to transcend its boundaries at the same time as they are constructed, to challenge depictions of Scottishness at the same time as they are in a process of evolution. In this openness to the present there is always a space left for possible reconfigurations of identity, an ethical search for beyondness. This sense of an 'elastic' ethical reading of the nation can readily be found in Rankin's later novels Set in Darkness and Fleshmarket Close. 
Many of the storylines in Set in Darkness centre around the construction of the new Scottish Parliament building at Holyrood, generating a sense of anticipation and uncertainty at what this might bring. Consequently, two murders take place at the site of the new Parliament, skeletons are exhumed from Queensberry House during its redevelopment and there are also cases of corruption and sexual assault. As in most of Rankin's novels, Rebus often traverses the city, observing many facets of Edinburgh life in his attempt to bring closure to these cases. In this sense Rebus is a symbolic filter through which society moves. Like many of his hard-boiled predecessors he makes numerous personal sacrifices in order to mediate the city in this way, to capture metaphorical snapshots of its place in time. Rebus reflects 'Most people just got on with their lives, but a detective's life was made up of other people's lives' (Rankin 2000: 223). While Rebus is in many ways 'an old-fashioned cop', anachronistically set in his ways, perhaps because of this he is also an apposite figure through which to illuminate societal transformations. Rebus therefore often acutely senses the demise of a more traditional Scotland:

Clusters of young people, standing in doorways and the corners of buildings. Voices low, eyes scanning. Rebus saw crime where none existed; or perhaps it was that he was attuned to the possibility of crime. Had the midnight revels always been this harsh and alarming? He didn't think so. The city was changing for the worse, and no amount of imaginative construction in glass and concrete could hide the fact. The old city was dying, wounded by these roars, this new paradigm of ... not lawlessness exactly, but certainly lack of respect: for surroundings, neighbours, self. (Rankin 2000: 331)

Rankin's interest in Jekyll and Hyde as a means of expressing aspects of Edinburgh's dark unconscious also extends to his ruminations on the unknowable forces of the future, a city torn between its historical foundations, its manifestations in the heritage industry on the one hand, and the sense that this is being re-shaped in dramatic and irrevocable 
ways on the other. However, this is not always entirely pessimistic. In another of his travels, Rebus reflects that this is "a city which seemed defined by its past as much as by its present, and only now, with the parliament coming, looking towards the future' (Rankin 2000: 222-3). While the gothic tones of the novel's title reinforce the ways in which Scottishness is firmly anchored to tradition, other aspects are simultaneously opened to speculation. Consequently, there is a deep scepticism as to what devolved powers may bring to Scotland, frequent reflections on the failed Referendum on Devolution in 1979 and the contentious issues surrounding it in order to help understand the present historical moment. Even Rebus, who usually fains disinterestedness in political discussion, seems curious as to what such changes might bring.

In Set in Darkness, both the puzzle of a murdered politician and the suspicious case of a vagrant in possession of vast sums of money revolve around one particular family, the Grieves. It is no co-incidence that the novel contains many references to the most famous 'Grieve' in Scottish literature, Christopher Murray Grieve (1892-1978) - or Hugh MacDiarmid, as he is more widely known, and the choice of this surname suggests another self-conscious engagement with Scottishness and national identity. For Rebus, MacDiarmid's poetry provides a vehicle though which to understand the notion of place. Inspecting the case of the skeleton behind the fireplace at the site of the new Parliament, Rebus reflects:

Queensberry House was unreal to him, the idea of a parliament itself the dream of some mad god: 'But Edinburgh is a mad god's dream/ Fitful and dark...' He'd found the words at the opening to a book about the city. They were from a poem by Hugh MacDiarmid. The book itself had been part of his recent education, trying to understand this home of his. (Rankin 2000: 12) 
In this novel the Grieve family are at the hub of political and cultural life, being labelled 'the clan' by 'a keen interviewer [who] had gone so far as to name them Scotland's first family' (Rankin 2000: 48). Although not blood-related, it is later revealed that MacDiarmid was a friend of this family during the 1950s. MacDiarmid is a therefore a spectral figure throughout this text, another reminder of previous struggles for Scottish national and cultural identity, in juxtaposition with the new. While in some ways he is represented as an anachronistic figure - for example, Alicia Grieve reflects that 'it was a different country then, you know' (Rankin 2000: 145), the presence of one of Scotland's most influential thinkers and poets acts as a self-conscious reminder of the enduring need to interrogate the state of the nation in current times nonetheless.

In Rebus's Scotland Rankin suggests that if the role of crime-fiction writers is to explain the world in some way, then 'being such a (relatively) small and (relatively) selfcontained country, Scotland can work as a microcosm for the wider world' (Rankin 2004: 178). This sense of Scotland as microcosm is evident in Rankin's later novel, Fleshmarket Close, where issues surrounding immigration and the status of asylum seekers are addressed. One of the main concerns of this novel is therefore the notion of inclusivity, and its exploration of this concept illuminates moral issues surrounding community, economic exploitation and cultural intolerance. In Fleshmarket Close Rebus attempts to solve a murder in 'Knoxland', a fictional housing estate on the fringes of the city, and this quest also takes him further afield to 'Whitemire', a rural detention centre for asylum seekers. Once again, Scotland is depicted as a country of contradictions, caught between old and the new, between the heritage culture of Edinburgh Castle on the one hand and the global economy epitomised by multinational chains such as Starbucks 
on the other. Sensing the racist bigotry of others around him, Rebus is keen to point out that 'we are a mongrel nation, always have been' (Rankin 2004: 124). However, despite Rebus's pleas for tolerance he also visualises contemporary Scotland in relatively dark, dystopian terms, as 'a fine, brave new world awaiting the new parliament. An ageing country dispatching its talents to the four corners of the globe... unwelcoming to visitor and migrant alike' (Rankin 2004: 170). The sense of cultural insecurity generated by this confused self-image is highlighted when Rebus, casually browsing in a bookstore with a fellow colleague, picks up a book on how Scotland invented the modern world and then 'looked around to make sure they weren't in the fiction section' (Rankin 2004: 210). Lurking at the heart of Rankin's fictions is therefore the notion that if Scotland is a microcosm of the modern world, then it is one without certainties. While exploring the dark, 'messy complexities' of modern Scottish life, much of Rankin's fiction nevertheless also demonstrates a deep respect for and connection with place, exploring the positive potential of Scottishness at the same time as it is being critiqued. Arguably, it is in this very ambivalence that the ethical potential of his fiction lies.

In The Ethics of Reading, J. Hillis Miller suggests that there is, of necessity, an ethical moment in the act of reading, that reading continually exposes the reader to alterity and the need to interpret in unexpected ways. In this text, Miller is primarily interested in the ways in which reading is always deferred, so that a final ethical analysis can never be reached. Consequently, it is in the process of reading that subjects engage with the ethical, yet with the knowledge that this can contain no ultimate telos. However, as he points out, in this subjective engagement, there is also a mediation with the ethical, a self-conscious recognition of the ought through which the reader must then negotiate 
himself or herself. Connected to the ethical process of reading, then, is also the recognition of unreadability, where the reader has the knowledge that the ethical can never be completely 'understood', that because the ethical cannot finally be captured, this is precisely why it is ethical - that the reader will always have more work to do.

For some critics, such as Berges, the ethical impetus in Rankin's fiction lies in the ways in which it forces us to engage with pragmatic issues on a 'case by case basis' in order to reach conclusions about the world in which we live. Alternatively, following J. Hillis Miller, perhaps the ethical drive of these novels lies in the ways in which they resist such categorisation, the ways in which they engage with aspects of unreadability, highlighting a deferral of closure. This sense of an ethical resistance to reading texts in pragmatic, moralistic ways has been integral to ethical debates in literary studies in recent decades. In his book Ethics, Theory and the Novel, for example, David Parker suggests that:

Ethical or moral answer-giving is what ultimately fails to satisfy interest, especially if it is of a kind that suppresses other sorts of answers. Those works that most sustain interest in the long run are the ones that present both interference and dynamic relationships between different ethical systems or conceptions. (Parker 1994: 197)

Perhaps a more satisfying way of examining the ethical potential of Rankin's fiction therefore lies in this sense of 'interference' generated in his texts, that instead of providing moral guidance these novels encourage a process of investigation into contemporary Scotland and Scottishness that cannot be so neatly tied up. If crime fiction

\footnotetext{
${ }^{3}$ In this reading Miller is indebted to de Man's Allegories of Reading and his notion of the impossibility of reading. "The category of the ethical or of "ethicity" intervenes, for de Man, just at this point where the act of reading bars access to an understanding of the act of reading. We can do it. We can read, but we cannot understand what it is we are doing. This means that what we do is always aberrant, since the only thing worth understanding is Reading itself, the ground and foundation of the whole of human life, for de Man.
} 
is good for you, then perhaps the ethical challenge placed on the reader is to attempt to make sense of the 'messy complexities' of these texts, yet with the ultimate knowledge that such readings must always remain provisional.

\section{ACKNOWLEDGEMENTS}

I am grateful to Professor Berthold Schoene (Manchester Metropolitan University, UK) for his comments on an earlier draft of this article.

\section{WORKS CITED}

Auster, Paul (1987), The New York Trilogy, London: Faber.

Berges, Sandrine (2003), 'The Hardboiled Detective as Moralist: Ethics in Crime Fiction', www.bilkent.edu.tr/ berges/The\%20Hardboiled\%20Detective\%20and\%20Virtue $\% 20$ Ethics.doc

Booth, Wayne C. (1988), The Company we Keep: An Ethics of Fiction, Berkeley: University of California Press

Duncan, Paul (2000), Noir Fiction: Dark Highways, Harpenden: Pocket Essentials.

Mandel, Ernest (1984), Delightful Murder: A Social History of the Crime Story, London: Pluto Press.

Miller, J. Hillis (1987), The Ethics of Reading, New York: Columbia University Press.

Nairn, Tom (1970), 'Three Dreams of Scottish Nationalism, in Karl Miller (ed.), Memoirs of a Modern Scotland, London: Faber, pp.34-54

Nussbaum, Martha C. (1990), Love's Knowledge: Essays on Philosophy and Literature, New York: Oxford University Press

Parker, David (1994), Ethics, Theory and the Novel, Cambridge: Cambridge University Press.

Plain, Gill (2002), Ian Rankin's Black and Blue: A Reader's Guide, London: Continuum.

The making of ethical judgements and demands is one necessary feature of this failure to read.' (Miller 1987: 48). 
Rankin, Ian (2005), Rebus's Scotland: A Personal Journey, London: Orion Books.

Rankin, Ian (2004), Fleshmarket Close, London: Orion Books.

Rankin, Ian (2000), Set in Darkness, London: Orion Books.

Rankin, Ian (1999), 'Why Crime Fiction Is Good for You?', Edinburgh Review, 102, pp. 9-16.

Rankin, Ian (1997), Black and Blue, London: Orion Books. 